\title{
Efek integrated nutrition programme terhadap profil lipid dan komposisi tubuh pada remaja obes
}

The effect of integrated nutrition programme on lipid profile and body composition among adolescent obesity

\author{
Martha Ardiaria $^{1}$, Erin Ratna Kustanti ${ }^{2}$, Ria Purnawian Sulistiani ${ }^{1}$, Etika Ratna Noer ${ }^{1}$
}

'Departemen Ilmu Gizi Fakultas Kedokteran, Universitas Diponegoro

${ }^{2}$ Fakultas Psikologi, Universitas Diponegoro

\begin{abstract}
Background: Obesity is a serious public health issue increasingly in the adolescent. Obesity in adolescence will continue into adulthood and lead to later health problems. The adolescent has high food dense calories which high fat and low in fiber that can trigger obesity. Integrated Nutrition Programme (INP) is an intervention model for obesity with an emphasis on a low-calorie diet, low fat, high fiber, moderate physical activity, and nutrition counseling. Objective: This study aimed to evaluate the effect of INP on lipid profile and body composition in obese adolescents. Methods: Quasi-experimental study pre-post trial design with a total of subjects 18 obese adolescents. Duration of intervention in subjects for four weeks with a hypocaloric diet, low fat, high fiber, and prepared by a dietician. Moderate exercise and dietary counseling were conducted on the subject regularly. Bodyweight (BW) and waist circumference (WC) were monitored once a week. Food record intake is done before and during the intervention. Results: The mean weight loss of $1.55 \mathrm{~kg}$. There is a difference in mean $B W, W C$, and $B M I(p<0.01)$, whereas there were no significant differences in lipid profiles and body composition between before and after the intervention. Conclusions: INP can significantly affect weight loss, BMI, and WC as well as a significant increase in physical activity.
\end{abstract}

KEYWORDS: adolescent obesity; integrated nutrition programme; lipid profile

\begin{abstract}
ABSTRAK
Latar belakang: Obesitas pada usia remaja akan berlanjut hingga dewasa dan menimbulkan masalah kesehatan di kemudian hari. The National Health and Nutrition Examination Survey (NHANES) memperkirakan 80\% remaja yang obesitas akan tetap obesitas ketika dewasa. Remaja saat ini memiliki pola konsumsi tinggi kalori, tinggi lemak, tinggi garam, dan rendah serat yang dapat memicu obesitas. Integrated Nutrition Program (INP) merupakan konsep model intervensi komprehensif untuk remaja obesitas dengan penekanan pada asupan diet rendah kalori, rendah lemak, tinggi serat, dan aktivitas fisik serta konseling gizi. Tujuan: Penelitian ini ingin mengetahui efektivitas INP dalam memperbaiki profil lipid dan komposisi tubuh pada remaja obes. Metode: Penelitian quasi eksperimental dengan jumlah subjek 18 remaja obes. Pemberian intervensi pada subjek selama 4 minggu dengan diet rendah kalori, rendah lemak, dan tinggi serat yang diolah oleh ahli gizi. Olahraga yang diberikan adalah senam aerobik 2 kali/ minggu serta pemberian konseling gizi. Pengukuran antropometri, asupan makan, dan pemeriksaan biokimia dilakukan sebelum dan sesudah intervensi. Hasil: Rerata penurunan berat badan subjek sebesar 1,55 kg dalam kurun waktu 4 minggu. Ada perbedaan rerata BB, LP, dan IMT yang signifikan $(\mathrm{p}<0,01)$, tetapi tidak ada perbedaan profil lipid dan komposisi tubuh sebelum dan setelah intervensi INP ( $p>0,05)$ Simpulan: INP dapat menurunkan berat badan, IMT dan LP serta peningkatan aktivitas fisik secara signifikan.
\end{abstract}

KATA KUNCI: remaja obes; integrated nutrition programme; profil lipid 


\section{PENDAHULUAN}

Obesitas adalah penyakit metabolik yang terjadi akibat keseimbangan energi positif secara kronis dan ditandai dengan akumulasi jaringan adiposa di dalam tubuh $(1,2)$. Konsekuensi dari obesitas ini cukup besar untuk terjadinya penyakit kronis seperti diabetes mellitus tipe-2, jantung koroner, dan kanker (3). Kenaikan berat badan lebih banyak terjadi pada usia muda 18-25 tahun yaitu masa puncak perkembangan. Fase remaja termasuk periode kritis karena masa eksplorasi diri, egosentris, dan ketidakstabilan emosi (4). Obesitas mudah terjadi pada usia remaja karena didukung oleh faktor gaya hidup hedonis dan sedentary (5-8). Obesitas pada usia remaja akan berlanjut hingga dewasa dan menimbulkan masalah kesehatan di kemudian hari. The National Health and Nutrition Examination Survey (NHANES) memperkirakan $80 \%$ remaja obes akan menetap hingga dewasa. Penelitian terhadap remaja usia 12-19 tahun di Amerika menunjukkan dari 34\% remaja yang mengalami obesitas, lebih dari $32 \%$ diantaranya kemudian diketahui tetap obesitas hingga usia dewasa (9). Prevalensi remaja obes usia 15-18 tahun di Indonesia naik sebesar lima kali lipat, dari 1,4 menjadi 7,3\% dari tahun 2007 ke 2013 (10).

Transisi gizi telah melanda di negara berkembang termasuk Indonesia. Transisi gizi ini mengakibatkan perubahan pola makan masyarakat sehingga kejadian obes meningkat (11). Pola perilaku makan mengalami pergeseran, seperti konsumsi makanan olahan yang semakin tinggi dan kemudahan mengakses restoran cepat saji (12). Studi longitudinal di Cina melaporkan adanya peningkatan konsumsi lemak (49\% dari energi total) pada remaja (13). Sementara konsumsi makanan berisiko untuk kesehatan pada masyararakat Indonesia cukup tinggi, yaitu konsumsi makanan manis 53\% dan berlemak $41 \%$ (10). Studi lain melaporkan bahwa remaja obes di India memiliki kebiasaan konsumsi makanan tinggi lemak serta rendah asupan sayur dan buah (8). Selain dari asupan tinggi energi, kebiasaan hidup sedentari berperan besar terhadap kejadian obes pada remaja. Angka aktivitas fisik menurut Riskesdas 2013 pada remaja usia 15-19 tahun sebesar 25\% (10). Studi menunjukkan aktivitas fisik rendah menjadi penyebab terjadinya obes remaja. Penelitian sejenis menyimpulkan hubungan yang kuat antara pola diet dan kebiasaan sedentari dengan polimorfisme gen pada remaja putri obes (14).

Risiko metabolik dari obes pada remaja telah banyak dilaporkan, seperti gangguan metabolisme glukosa dan lipid (10). Kondisi obes akan meningkatkan pelepasan nonesterified fatty acid (NEFA), memicu aktivitas makrofag serta peningkatan produk proinflamasi. Inflamasi ini berjalan secara kronik (low grade chronic inflammation) hingga memperburuk profil lipid seperti peningkatan trigliserida (TG), penekanan high density lipoprotein (HDL), dan berujung pada resistensi insulin.

Upaya strategis dan signifikan untuk menurunkan berat badan pada remaja adalah modifikasi gaya hidup melalui diet dan aktivitas fisik (15). Studi meta-analisis menunjukkan efek intervensi multidisiplin pada remaja obes dapat menurunkan derajat obesitas dibandingkan intervensi tunggal $(16,17)$. Saat ini, memberikan intervensi diet komprehensif secara personal lebih diutamakan. Integrated Nutrition Program (INP) sebagai konsep model intervensi diperlukan untuk membantu menangani masalah obesitas pada remaja dengan pendekatan personal. Modifikasi perilaku melalui pemberian diet hipokalori, tinggi serat, dan konseling gizi disusun secara khusus untuk subjek remaja.

Berbagai bentuk intervensi telah banyak diberikan untuk membantu individu yang mengalami obesitas. Secara garis besar, intervensi pada obesitas bertujuan untuk memperbaiki parameter obesitas secara umum. Penelitian modifikasi perilaku yang berfokus komposisi zat gizi dan dosis olahraga pada perubahan profil lipid pada remaja obes di Indonesia belum banyak dilaporkan. Penelitian ini bertujuan untuk mengetahui efek INP dalam memperbaiki profil lipid dan komposisi tubuh pada remaja obes.

\section{BAHAN DAN METODE}

Penelitian ini merupakan penelitian quasi experimental yang dilaksanakan pada bulan AgustusSeptember 2017 di Universitas Diponegoro, Semarang, Jawa Tengah. Setiap subjek mendapatkan intervensi INP berupa diet hipokalori (1.500-1.600 kalori), rendah lemak, tinggi serat (25-30 g), dan senam aerobik 2x/minggu per sesi 45 menit. Penelitian ini diawali 
dengan proses skrining awal subjek penelitian dengan pengukuran antropometri. Subjek penelitian adalah mahasiswa Universitas Diponegoro yang memenuhi kriteria inklusi yaitu usia 18-19 tahun, memiliki IMT/U lebih dari atau sama dengan 95 , bersedia menandatangani informed consent, berada di lokasi penelitian selama penelitian, dan tidak memiliki riwayat penyakit kronis. Total subjek yang memenuhi kriteria inklusi sejumlah 18 orang dan bersedia menandatangani informed consent. Subjek tidak dikelompokkan berdasarkan jenis kelamin.

Penimbangan berat badan dipantau setiap seminggu sekali. Pengukuran data antropometri dan pengambilan data 24-hour dietary recall dilakukan oleh tenaga terlatih. Metode penimbangan berat badan dengan timbangan digital SECA ${ }^{\circledR}$ (ketelitian $0,1 \mathrm{~kg}$ ) dan pengukuran tinggi badan dengan microtoise (ketelitian $0,1 \mathrm{~cm}$ ). Pengukuran aktivitas fisik dengan menggunakan kuesioner IPAQ. Variabel bebas dalam penelitian ini adalah pemberian diet hipokalori, tinggi serat, dan senam aerobik sedangkan variabel tergantung adalah profil lipid dan komposisi tubuh.

Pemeriksaan kadar kolesterol total, trigliserida, low density lipoprotein (LDL), dan HDL dilakukan di Laboratorium Rumah Sakit Nasional Diponegoro dengan alat autoanalyzer. Subjek diharuskan puasa 10 jam sebelum pengambilan darah yang dilakukan pada pembuluh darah vena sebanyak $5 \mathrm{ml}$. Riwayat diet sebelum penelitian diketahui dengan pengambilan data recall $3 \times 24$ jam, yaitu 2 hari weekdays dan 1 hari weekend untuk mengetahui pola konsumsi subjek. Diet hipokalori diberikan dengan tetap memperhitungkan kebutuhan kalori setiap subjek. Diet ini disusun dan diolah oleh ahli gizi dan subjek mengambil menu diet setiap hari untuk makan siang dan sore. Subjek diberi latihan aktivitas fisik berupa senam aerobik intensitas sedang yaitu dua kali per minggu selama 45 menit per sesi. Senam aerobik tersebut dipandu oleh trainer dari bidang keolahragaan. Subjek juga dianjurkan untuk menambah aktivitas fisik sesuai dengan hasil komitmen masing-masing selama konseling.

Intervensi INP berdasarkan riset sebelumnya yang memberikan intervensi diet selama 3 minggu. Konseling diberikan secara rutin per individu untuk mendapatkan problem solving dalam mengatasi hambatan menjalani INP serta meningkatkan kepatuhan. Edukasi dan konseling dilakukan oleh ahli gizi yang mencakup empat materi yaitu, total kalori asupan harian, pemilihan bahan makanan serta porsi rendah lemak dan tinggi serat, pentingnya aktivitas fisik, mengatasi hambatan diet dan penguatan motivasi. Kepatuhan mengikuti INP dipantau dalam log book diet dan aktivitas fisik yang wajib diisi subjek tiap harinya. Analisis data menggunakan uji paired t-tes karena data berdistribusi normal. Penelitian ini telah mendapatkan persetujuan etik dari Komisi Etik Penelitian Kesehatan (KEPK) Fakultas Kedokteran Universitas Diponegoro-RS Kariadi Semarang no 119/ EC/FK-RSDK/III/2017.

\section{HASIL}

Menurut karakteristik subjek menunjukkan bahwa rerata usia dalah 19 tahun; IMT $32,79 \mathrm{~kg} / \mathrm{m}^{2}$; lingkar perut 100,64 cm; dan berat badan $84,98 \mathrm{~kg}$. Berdasarkan Tabel 1, terjadi penurunan rerata BB, IMT, LP, kadar total kolesterol, trigliserida, LDL, dan terjadi peningkatan aktivitas fisik setelah intervensi INP.

Hasil analisis menunjukkan perbedaan signifikan berat badan, IMT, dan LP sebelum ( baseline) dan sesudah (4 minggu) intervensi INP $(\mathrm{p}<0.001)$ pada masingmasing kelompok laki-laki dan perempuan. Demikian juga ditemukan perbedaan signifikan aktivitas fisik dan total asupan energi sebelum dan sesudah intervensi INP $(\mathrm{p}<0.001)$, tetapi tidak dengan profil lipid sebelum dan sesudah intervensi $(\mathrm{p}>0.05)$.

Subjek mengalami penurunan asupan karbohidrat, protein, dan lemak selama intervensi seperti terlihat pada Gambar 1. Berdasarkan hasil penggalian data riwayat diet sebelum penelitian, ditemukan jenis asupan karbohidrat yang banyak dikonsumsi adalah jenis karbohidrat simpleks seperti mie, minuman manis, dan tepung. Setelah intervensi, subjek mengalami perubahan konsumsi sumber karbohidrat kompleks plus tinggi serat, seperti oat, snack whole grain, ataupun roti gandum utuh. Hal ini tampak pada peningkatan asupan serat dari 9,3 menjadi 25,2 g. Demikian juga dengan perubahan aktivitas fisik sebelum dan setelah intervensi INP yang menunjukkan peningkatan rerata aktivitas fisik dari 673,18 menjadi 1.228,53 METs. Peningkatan aktivitas fisik disebabkan oleh motivasi subjek yang tinggi untuk 
Tabel 1. Perbedaan parameter obesitas dan kualitas diet pre-post intervensi INP

\begin{tabular}{lcccccc}
\hline & \multicolumn{3}{c}{ Laki-Laki (n=7) } & \multicolumn{3}{c}{ Perempuan (n=11) } \\
\hline & Baseline & $\mathbf{4}$ minggu & p & Baseline & 4 minggu & p \\
\hline BB $(\mathrm{kg})$ & $90,98 \pm 12,37$ & $88,70 \pm 12,82$ & $0,007^{*}$ & $81,70 \pm 3,49$ & $80,01 \pm 8,83$ & $0,004^{*}$ \\
IMT $\left(\mathrm{kg} / \mathrm{m}^{2}\right)$ & $32,90 \pm 3,70$ & $32,00 \pm 4,08$ & $<0,001^{*}$ & $32,74 \pm 3,49$ & $31,92 \pm 3,35$ & $0,001^{*}$ \\
LP $(\mathrm{cm})$ & $104,58 \pm 6,00$ & $99,67 \pm 7,55$ & $0,002^{*}$ & $98,50 \pm 10,54$ & $95,64 \pm 10,10$ & $<0,001^{*}$ \\
Total kolesterol(mg/dL) & $183,71 \pm 24,75$ & $178,00 \pm 30,79$ & 0,836 & $169,72 \pm 29,09$ & $164,55 \pm 26,56$ & 0,261 \\
TG (mg/dL) & $129,00 \pm 48,54$ & $108,42 \pm 30,88$ & 0,560 & $110,09 \pm 48,99$ & $104,64 \pm 28,54$ & 0,778 \\
HDL (mg/dL) & $45,67 \pm 8,24$ & $41,67 \pm 5,75$ & 0,306 & $48,27 \pm 9,21$ & $49,00 \pm 8,11$ & 0,830 \\
LDL (mg/dL) & $115,28 \pm 26,53$ & $113,85 \pm 31,02$ & 0,763 & $100,18 \pm 29,26$ & $92,91 \pm 23,31$ & 0,250 \\
Aktifitas fisik & $752,33 \pm 359,31$ & $1.391,67 \pm 542,78$ & $<0,001^{*}$ & $630,00 \pm 144,89$ & $1.139,55 \pm 318,48$ & $<0,001^{*}$ \\
(MET menit/minggu) & & & & & & \\
Asupan energi (Kkal) & $2.597,05 \pm 360,47$ & $1.708,97 \pm 230,21$ & $<0,001^{*}$ & $2.573,46 \pm 526,42$ & $1.661,64 \pm 349,23$ & $<0,001^{*}$ \\
\hline
\end{tabular}

*Paired t-test; $\mathrm{BB}=$ berat badan; IMT=indeks massa tubuh; LP=lingkar perut;

$\mathrm{TG}=$ trigliserida; $\mathrm{HDL}=$ high density lipoprotein $\mathrm{LDL}=$ low density lipoprotein $; \mathrm{MET}=$ metabolic equivalent task

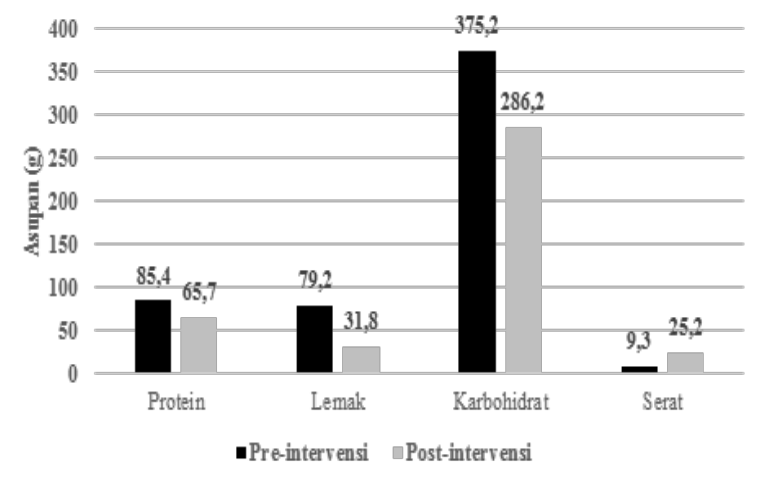

Gambar 1. Grafik perubahan asupan zat gizi

menurunkan berat badan dan tingkat kepatuhan terhadap intervensi INP yang baik.

\section{BAHASAN}

\section{Karakteristik subjek}

Subjek tergolong usia remaja periode akhir (usia 17-19 tahun) yang merupakan masa kritis terhadap peningkatan berat badan. Tingkat pertambahan berat badan terjadi paling besar di usia ini hingga di usia 25 tahun (4). Hal mendasar yang menyebabkan obesitas remaja adalah perilaku makan yang salah dan gaya hidup sedentary (18).

\section{Indikator antropometri}

Indikator antropometri berupa berat badan, indeks massa tubuh, dan lingkar pinggang subjek mengalami penurunan yang bermakna setelah menjalani intervensi selama empat minggu. Hasil penelitian ini menunjukkan bahwa modifikasi perilaku yang terdiri dari pengaturan asupan energi, peningkatan aktivitas fisik, dan konseling gizi mampu menurunkan indikator antropometri untuk obesitas secara signifikan. Sejalan dengan penelitian lain bahwa penurunan asupan kalori sebesar $300 \mathrm{Kkal}$ per hari selama empat minggu telah mampu menurunkan berat badan dan lingkar pinggang (19). Adanya penurunan asupan hampir $1.000 \mathrm{Kal}$ per hari dan peningkatan aktivitas fisik sebesar dua kali lipat dalam kurun waktu empat minggu terjadi pada penelitian ini. Penurunan indikator antropometri tersebut kemungkinan terjadi karena adanya balans energi negatif.

Olahraga merupakan cara non-farmakologis yang biasa dikombinasikan dengan pembatasan kalori untuk mengatasi obesitas dan pengaturan berat badan. Olahraga tidak selalu dapat menurunkan nafsu makan, tetapi menciptakan keadaan balans energi negatif yang pada akhirnya akan menurunkan berat badan. Olahraga yang dilakukan pada penelitian ini adalah olahraga jenis aerobik intensitas sedang dengan durasi 150 menit setiap minggu selama 4 minggu. Penurunan berat badan dan indikator antropometri lain pada penelitian ini disebabkan balans energi negatif yang terjadi karena penurunan asupan energi dan peningkatan energy expenditure.

\section{Profil lipid}

Pembatasan kalori, olahraga aerobik, dan konseling gizi mampu menurunkan jumlah kolesterol total, 
kolesterol LDL, dan trigliserida pada penelitian ini. Jumlah kolesterol HDL yang tidak meningkat disebabkan oleh penurunan asupan lemak dan berat badan. Perbaikan profil lipid antara lain disebabkan oleh adanya restriksi kalori. Komposisi karbohidrat ( $<60 \%)$ dan lemak $(<30 \%)$ yang terdapat pada menu serta asupan serat lebih dari 25 gram mampu menurunkan kadar kolesterol total, kolesterol LDL, dan trigliserida.

Diet ini disusun dengan tetap mengacu prinsip diet seimbang, dengan proporsi zat gizi karbohidrat $60 \%$, lemak $25 \%$, dan protein $15 \%$. Intervensi pada subjek obes harus tetap dikombinasikan dengan diet dan olahraga. Studi lain pada subjek remaja obes yang diberikan diet dan olahraga menunjukkan penurunan IMT dan lingkar pinggang lebih besar dibandingkan intervensi tunggal (20). Pemberian konseling gizi membuat subjek penelitian menjadi lebih mampu memilih bahan makanan yang baik dan motivasi lebih terjaga selama menjalankan program INP.

\section{SIMPULAN DAN SARAN}

Intervensi INP yang berprinsip diet hipokalori mengandung tinggi serat rendah lemak serta peningkatan aktivisitas fisik dapat menurunkan berat badan, IMT dan LP. Kelemahan pada penelitian ini adalah lama penelitian tergolong singkat sehingga belum cukup menurunkan profil lipid secara signifikan.

\section{UCAPAN TERIMA KASIH}

Penelitian ini didanai oleh Universitas Diponegoro, Kementrian Riset Teknologi dan Pendidikan Tinggi tahun 2017.

\section{Pernyataan konflik kepentingan}

Penulis menyatakan tidak ada konflik kepentingan dengan pihak-pihak yang terkait dalam penelitian ini.

\section{RUJUKAN}

1. Bray G, Bouchard C. Handbook of obesity: epidemiology, etiology, and physiopathology. 3rd ed. USA: CRC Press Taylor \& Farncis Group; 2014.

2. Luglio HF. Obesitas translasional: aspek klinis dan molekuler dari kejadian obesitas. Yogyakarta: Gadjah Mada University Press; 2017.
3. Lakshman R, Elks CE, Ong KK. Childhood obesity. Circulation. 2012;126(14):1770-9. doi: 10.1161/ CIRCULATIONAHA.111.047738

4. Lanoye A, Brown KL, LaRose JG. The transition into young adulthood: a critical period for weight control. Curr Diab Rep. 2017;17(11):114. doi: 10.1007/s11892017-0938-4

5. Fatusi AO, Hindin MJ. Adolescents and youth in developing countries: health and development issues in context. J Adolesc. 2010;33(4):499-508. doi: 10.1016/j. adolescence.2010.05.019

6. Al-Hazzaa HM, Abahussain NA, Al-Sobayel HI, Qahwaji DM, Musaiger AO. Lifestyle factors associated with overweight and obesity among saudi adolescents. BMC Public Health. 2012;12:354. doi: 10.1186/1471-245812-354

7. Kelly AS, Barlow SE, Rao G, Inge TH, Hayman LL, Steinberger J, et al. Severe obesity in children and adolescents: identification, associated health risks, and treatment approaches: a scientific statement from the American Heart Association. Circulation. 2013;128(15):1689-712. doi: 10.1161/CIR.0b013e3182a5cfb3

8. Rathi N, Riddell L, Worsley A. Food consumption patterns of adolescents aged 14-16 years in Kolkata, India. Nutr J. 2017;16(1):50. doi: 10.1186/s12937-017-0272-3

9. Jelalian E, Steele RG. Handbook of childhood and adolescent obesity. New York: Springer; 2008.

10. Kementerian Kesehatan Republik Indonesia. Laporan riset kesehatan dasar (Riskesdas). Jakarta: Kemenkes RI; 2013.

11. Usfar AA, Lebenthal E, Atmarita, Achadi E, Soekirman, Hadi H. Obesity as a poverty-related emerging nutrition problems: the case of Indonesia. Obes Rev. 2010;11(12):9248. doi: 10.1111/j.1467-789X.2010.00814.x

12. Popkin BM, Adair LS, Ng SW. Global nutrition transition and the pandemic of obesity in developing countries. Nutr Rev. 2012;70(1):3-21. doi: 10.1111/j.17534887.2011.00456.x

13. Cui Z, Dibley MJ. Trends in dietary energy, fat, carbohydrate and protein intake in Chinese children and adolescents from 1991 to 2009. Br J Nutr. 2012;108(7):1292-9. doi: 10.1017/ S0007114511006891

14. Apovian CM. The causes, prevalence, and treatment of obesity revisited in 2009: what have we learned so far? Am J Clin Nutr. 2010;91(1):277S-279S. doi: 10.3945/ ajen.2009.28473A

15. Boff R de M, Liboni RPA, Batista IP de A, de Souza LH, Oliveira M da S. Weight loss interventions for overweight and obese adolescents: a systematic review. Eat Weight Disord. 2017;22(2):211-229. doi: 10.1007/s40519-0160309-1

16. Al-Khudairy L, Loveman E, Colquitt JL, Mead E, Johnson RE, Rees K, et al. Diet, physical activity and behavioural 
interventions for the treatment of overweight or obese adolescents aged 12 to 17 years. Cochrane Database Syst Rev. 2017;6(6):CD012691. doi: 10.1002/14651858. CD012691

17. Luglio HF, Eurike D, Huriyati E, Julia M, Susilowati R. Gene-lifestyle interaction: The role of SNPs in UCP2 $-866 \mathrm{G} / \mathrm{A}$ and UCP3 $-55 \mathrm{C} / \mathrm{T}$ on dietary intake and physical activity in Indonesian obese female adolescents. Med J Nutrition Metab. 2016;9(2):87-93.

18. Sahoo K, Sahoo B, Choudhury AK, Sofi NY, Kumar R, Bhadoria AS. Childhood obesity: causes and consequences.
J Family Med Prim Care. 2015;4(2):187-92. doi: 10.4103/2249-4863.154628

19. Ard JD, Miller G, Kahan S. Nutrition interventions for obesity. Medi Clin North Am. 2016;100(6):1341-56. doi: 10.1016/j.mcna.2016.06.012

20. Ben Ounis O, Elloumi M, Ben Chiekh I, Zbidi A, Amri M, Lac G, et al. Effects of two-month physicalendurance and diet-restriction programmes on lipid profiles and insulin resistance in obese adolescent boys. Diabetes Metab. 2008;34(6 Pt 1):595-600. doi: 10.1016/j. diabet.2008.05.011 